\title{
Assessment of the Inhibitory Activity of Resin from Juniperus procera against the Mycilium of Pyrofomes demidoffi Dagnew Bitew*
}

Department of Microbial, Cellular and Molecular Biology, College of Natural Science, Addis Ababa University, Ethiopia

\begin{abstract}
Juniperus procera is an evergreen dioecious more seldom monoecius tree, which belongs to the family Cupressaceae and the only Juniper species, which is found in the mountains of East Africa and it is an important indigenous forest tree species in Ethiopia. However J. procera is subjected to a serious attack by the slow growing white heart-rot fungus, Pyrofomes demidoffii. Resin has been reported to be active against wood colonizing fungi, however, the role of resin of $J$. procera in protecting the tree from the attack of $P$. demidoffii is not known. Therefore this study has initiated to assess the inhibitory effect of resin from J.procera against a white rot fungi $P$. demidoffii. Resin and basidiocarps of $P$. demidoffii was collected from infected J. procera trees at Menagesha Suba Forest situated $30 \mathrm{~km}$ South West of Addis Ababa, Ethiopia. The antifungal activity of $J$. procera resin against $P$. demidoffii was tested using agar dilution assay technique and an impressive result was observed. The MIC value of resin extract was within the range of 5 to $6 \mathrm{mg} / 100 \mathrm{ml}$ MEAP. Phytochemical screening test for resin extract was done and it revealed the presence of alkaloids, saponins, terpenoids, phenolic compounds, flavenoides and fixed oils and the absence of carbohydrate, glycoside, steroids and fats. The crude extract of $J$. procera resin was fractionated into six fractions with column chromatography using different organic solvents and all fractions run on Thin Layer Chromatography (TLC) plate using benzene: methanol (18:6) and benzene: ethanol: ammonia (18:2:1). All fractions gave different retention factor $(\mathrm{Rf})$ in each developing solvents.
\end{abstract}

Keywords: Antifungal; Conifers; Fungicide; Heart rot; Phytochemical

\section{Introduction}

Juniperus procera is an evergreen dioecious, more seldom monoecius tree, which belongs to the family Cupressaceae and the only Juniper species, which is found in the mountains of East Africa and it is one of the two indigenous conifer species which found in Ethiopia [1].

It is naturally found in the central high lands of Ethiopia. Within the dry afromontane forests of the Ethiopian highlands, it dominates mainly between altitudes from 1800-3200 m above sea level, with the mean annual rainfall ranges from 500 to $1100 \mathrm{~mm}$ millimeters [2].

Natural forest is both an ecosystem and a resource: as an ecosystem it integrates diverse fauna, flora and the physical environment; as a resource it has various economic, ecological and social values [3]. $J$. procera forests of the afromontane areas of Ethiopia have considerable economic value at a local and national level [4]. It is a very important source of wood for timber and fuel. Its wood is hard and resistant to termites and fungal diseases. Because of these distinctive qualities, it is highly valued for the construction of houses, internal structures of churches, furniture and for poles. The tree is planted as ornamental and for its shade in homesteads [5]. Its fruits have also some medicinal values for curing headaches, skin diseases etc. Generally J. procera is a multipurpose tree, which results from its drought tolerant and easily adaptability [5].

Forest decline affects the ecosystem as well as the usefulness of forest as a resource [6]. Reports of forest decline and tree mortality have increased in recent years and are presently considered to be a major threat in temperate ecosystems [7].

In Ethiopia forest decline is identified as an important problem [8]. $J$. procera forest once covered a large part of the country. However, as a consequence of long-lasting and persistent human influence, it has been considerably depleted and reduced to some isolated patches [9].

Heart rot caused by the wood rot fungus known as Pyrofomes demidoffii also contribute a lot for the decline of J. procera forest [10]. Now it is included on the IUCN red list of endangered species [11].

Forest decline due to tree diseases is characterized by the interactions of predisposing abiotic factors and biotic agents that come together in an orderly fashion resulting in tree death [12]. Abiotic factors include natural branch thinning due to shading, pruning wounds, vandalism, frost or drought cracks, fire, lightning, insects that bore into the trunk or branches; knives and bicycles, automobiles and damage from machinery or construction which creates suitable condition for biotic factors [13]. Forest decline diseases play a direct role in the destruction of natural resources. Of which, fungal pathogens cause the most important losses [14]. As an example J. procera forest is subjected to a serious attack by the white heart-rot fungus, $P$. demidoffii [10].

$P$. demidoffii is the only serious pathogen of Junipers sp. It attacks the heart wood of the tree and creates cavities of various sizes and in case of serious infestation a large tree may be reduced to a mere shell [15]. It produce large, perennial, ungulate, adnate and broadly attached, brightly colored a woody upper surface, hoof-shaped fruiting body (conk) that is dark brown to nearly black in color. The lower (pore) surface is bright yellowish to orange-brown or pale brick-red with pores angular to round, 2-3 per $\mathrm{mm}$, occasionally larger in old specimens [10].

$P$. demidoffii is spread by airborne spores that infect host trees

${ }^{*}$ Corresponding author: Dagnew Bitew, Department of Microbial, Cellular and Molecular Biology, College of Natural Science, Addis Ababa University, Ethiopia, E-mail: btdagne@gmail.com

Received May 20, 2015; Accepted July 30, 2015; Published August 01, 2015

Citation: Bitew D (2015) Assessment of the Inhibitory Activity of Resin from Juniperus procera against the Mycilium of Pyrofomes demidoffi. J Plant Pathol Microb 6: 291. doi:10.4172/2157-7471.1000291

Copyright: (c) 2015 Bitew D. This is an open-access article distributed under the terms of the Creative Commons Attribution License, which permits unrestricted use, distribution, and reproduction in any medium, provided the original author and source are credited. 
through injuries and wounds. Generally heart rot fungi do not penetrate sound trees but require an opening into the heartwood or exposed dead sapwood adjacent to heartwood is a potential site for fungi to become established $[15,16]$.

Plants use several strategies to defend against damage caused by herbivores and pathogens. The defense system of conifers to biotic agents such as pathogens and herbivores consists of: (i) a constitutive; (ii) a preformed resin response; and (iii) an induced resin response that develops simultaneously and complements each other. The constitutive and preformed mechanisms exist in the absence of a pathogen and include tough outer bark, several classes of secondary metabolites and an elaborate network of resin ducts. However, the induced response and mechanisms are activated only when a pathogen or herbivore attacks the tree and consists of several classes of secondary metabolites and uses the network of pre-formed resin ducts [12].

Higher plants produce hundreds and thousands of different secondary metabolites, which are active against plant pathogens [17]. Many secondary metabolites of wood are toxic or inhibitory to pathogenic fungi [18]. Often, plant secondary metabolites may be referred to as plant natural products, in which case they illicit effects on other organisms [19].

Resin is a secondary metabolite secreted by many plants, particularly coniferous trees and it is one of the main lines of chemical and physical defense system in plant against herbivores and pathogens by physically cleanse wounds, expelling invaders and sealing off damaged tissue [2022].

The term "resin" also encompasses synthetic substances of similar mechanical properties thick liquids that harden into transparent solids. Other liquid compounds found in plants or exuded by plants, such as sap, latex, or mucilage, are sometimes confused with resin, but are not chemically the same. Saps, in particular, serve as nutritive function that resins do not. However, resins consist primarily of secondary metabolites or compounds that apparently play no role in the primary physiology of a plant [23].

In nature, many secondary metabolites play an important role in the protection of plants as antibacterial, antiviral, antifungal, insecticides and also against herbivores by reducing their appetite for such plants [24]. These active ingredients can be synthesized, making new chemical pesticides, or used in the form of extracts. It is expected that these measures will provide new tools for controlling this disease in the context of integrated pest management strategies [25].

Integrated Pest Management (IPM) means the careful consideration of all available pest control techniques and subsequent integration of appropriate measures that discourage the development of pest populations and keep pesticides and other interventions to levels that are economically justified and reduce or minimize risks to human health and the environment. IPM emphasizes the growth of a healthy crop with the least possible disruption to agro-ecosystems and encourages natural pest control mechanisms [26].

Despite the enormous socioeconomic importance of $J$. procera, it is declining at an alarming rate [4]. Therefore, the purpose of this study is to assess the inhibitory activity $J$. procera resin against its wood colonizing fungus, $P$. demidoffi, which will have a crucial role to prevent the decline J. procera by the infestation of $P$. demidoffii.

The hypothesis of this research is, based on critical observation of the presence of fruiting body of $P$. demidoffii in old $J$. procera trees, which have no or little amount of resin unlike that of young trees, which is not infested and have more resin. However, the role of the resin in protecting the tree from the pathogen is not known.

\section{Materials and Methods}

\section{Collection of resin from $J$. procera tree}

This study was conducted in Mycology Laboratory, Department of Microbial, Cellular and Molecular Biology, College of Natural Science, Addis Ababa University. Resin from J. procera was collected from Menagesha Suba Forest situated $30 \mathrm{~km}$ South West of Addis Ababa, Ethiopia. The resin was collected from living trees with and without decline symptom using autoclaved Stikine, ependroff and bottle, and dried at room temperature.

\section{Collection and cultivation of $P$. demidoffii}

Basidiocarps of $P$. demidoffi were collected from J. procera from the same forest using axe, basket and paper bag, so as to characterize and cultivate the fungus in the laboratory. Pieces of basidiocarp were transferred aseptically onto $20 \mathrm{ml}$ of malt extract agar (MEA) medium (OXOID). Inoculated plates were incubated at $25^{\circ} \mathrm{C}$ until young hyphae emerge, from which pieces of agar culture blocks were transferred to the same medium to obtain pure culture [27]. Although, its host was a diagnostic feature, the fungus was characterized morphologically by observing its hyphae and spore under light microscope, oil immersion magnification.

\section{Evaluation of culture media}

$P$. demidoffii is a slow growing $J$. procera inhabiting fungus; and there is no formal data which shows in which media it grows faster. In order to identify good growing medium for $P$. demidoffii $4 \mathrm{~mm}$ inoculum plug of it were taken using sterile cork borer and placed on ten different media Corn Meal Agar (CMA) medium (OXOID), Corn Meal Dextrose Agar (CMDA) (OXOID), Malt Extract Agar (MEA), Czapek Dox Agar (CDA) medium (OXOID), Potato Dextrose Agar (PDA) medium (OXOID), Oat Meal Agar (OMA) ( Rolled oats 30.0

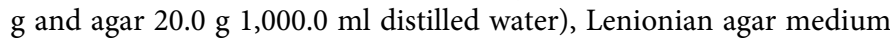
(LAM) (Peptone $0.625 \mathrm{~g}$, Maltose $6.25 \mathrm{~g}$, Malt extract $6.25 \mathrm{~g}, \mathrm{KH}_{2} \mathrm{PO}_{4}$ $1.25 \mathrm{~g}, \mathrm{MgSO}_{4}+7 \mathrm{H}_{2} \mathrm{O} 0.625 \mathrm{~g}$ and Agar $20.00 \mathrm{~g}$ per $1,000.0 \mathrm{ml}$ distilled water), Malt Extract Agar with Peptone (MEAP) (Malt extract 20.0 g, Peptone 1.0 g, Glucose 20.0 g, Agar 20.0 g per 1,000.0 ml distilled water), Malt Extract Agar with Juniper Extract (MEAJE) (Malt extract 20.0 g, juniper extract $10 \mathrm{~g}$, Glucose $20.0 \mathrm{~g}$, Agar 20.0 g per $1,000.0 \mathrm{ml}$ distilled water) and Juniper Extract (JE) (Juniper extract $20.0 \mathrm{~g}$, Agar $20.0 \mathrm{~g}$ per $1,000.0 \mathrm{ml}$ distilled water) and the colony diameters were traced in four days interval in each medium.

\section{Solvent selection for the extraction of resin}

The selection of the solvent was based on its ability to dissolve the resin completely. In addition the cost and availability of the solvent were taken into account. Different six solvents (cold water, hot water, methanol, ethanol, ethyl acetate and chloroform) were used to dissolve the resin, that gives clue, as which solvent is better to extract the resin material. The resin was suspended in solvents listed above separately and shaken for about 6 hours on the shaker.

\section{Preparation of resin extracts}

The resin material collected from trees was air dried under shade, in Mycology Laboratory, Department of Microbial, Cellular and Molecular Biology, College of Natural Science, Addis Ababa University. Then after drying the resin powder was dissolved by four different organic solvents, which dissolve the resin in different degrees 
during solvent selection for extraction of resin (chloroform, Ethanol, Ethyl acetate and methanol) after 6 hours of shaking on the shaker and dried using Rota Vapor to test its antifungal activity.

\section{Antifungal assays}

Effect of crude resin extract on fungal mycelium growth: The inhibitory effect of resin against the mycelial growth of test fungal species was undertaken using agar dilution method [28]. Different concentrations of resin sample were weighed $(1.5 \mathrm{mg}, 2.5 \mathrm{mg}, 3 \mathrm{mg}, 4$ $\mathrm{mg}, 5 \mathrm{mg}$ and $6 \mathrm{mg}$ ) and dissolved in different solvents to test against $P$. demidoffii. Solvents were removed using Rota Vapor and each concentration of resin extract was added into a separate $250 \mathrm{ml}$ flasks which contains $100 \mathrm{ml}$ of MEAP, on which $P$. demidoffii was grown better during attempting media formulation, and poured in $90 \mathrm{~mm}$ Petri plate. Pure media was used as a control. Then inoculum plugs (4 mm diameter) of test fungi were cut using a cork borer from the actively growing margin of the source of fungus and transferred to the centre of each study plate within $1 \mathrm{~h}$ after the resin had been poured and incubated at $25^{\circ} \mathrm{C}$. At the end of the incubation period antifungal activity of the resin was evaluated by measuring the diameter growth of the fungi (including diameter of the disk) using ruler. Growths diameters were traced at four days interval about five times after inoculation [12]. Data were expressed as the means of diameter growth, growth rate and percentage of inhibition, of the growth of the fungi in the presence of any of the concentrations of resin. Percentage of mycelial inhibition was calculated in relation to the control using the following formula: $\%$ of inhibition=[1 - (fungal growth in experimental test/Control growth)] x 100 [29].

And the growth rate was calculated using the formula: GR=G2 G1/T2 - T1. Where: G2=growth attained at the final time, G1=Growth attained at the initial time, T2=Final time and T1=initial time [28].

\section{Determination of minimum inhibitory concentration (MIC) of crude resin and fungicides}

Based on the preliminary antifungal screening, ethyl acetate and methanol extract of resin revealed potent antifungal activity. Thus the MIC value of ethyl acetate and methanol extracts of resin and those commercial fungicides were undertaken using Agar dilution method [12]. Different concentrations of resin were weighted ( $4 \mathrm{mg}, 5 \mathrm{mg}, 6$ $\mathrm{mg}, 7 \mathrm{mg}$ and $8 \mathrm{mg}$ ) dissolved in ethyl acetate and methanol and dried using Rota Vapor. And different concentrations of fungicides $(0.1 \mathrm{mg}$, $0.25 \mathrm{mg}$ and $0.5 \mathrm{mg}, 0.75 \mathrm{mg}$ and $1 \mathrm{mg}$ similar for each fungicide) were also weighted. Then each concentration of resin and fungicides were separately added into separate $250 \mathrm{ml}$ flasks containing $100 \mathrm{ml}$ of MEAP after autoclaved and cooled and poured in $90 \mathrm{~mm}$ Petri plate. $P$. demidoffi $i$ was grown on MEAP medium for $10-14$ days at $25^{\circ} \mathrm{C}$.

Then inoculum plug ( $4 \mathrm{~mm}$ diameter) of $P$. demidoffii was cut using a cork borer from the actively growing margin of the source of fungus and transferred to the centre of each study plate within $1 \mathrm{~h}$ after the resin had been poured and incubated for 20 days at $25^{\circ} \mathrm{C}$. At the end of the incubation period, the plates were evaluated for the presence or absence of fungal growth. The MIC was the minimum concentration of resin extract and fungicides that inhibited the growth of the test organism completely.

The MFC (Minimum Fungicidal Concentration) was determined by subculturing the inoculum plug from the plate which did not show any growth during the MIC test by placing on new MEAP plates to determine whether the resin and fungicides were fungistatic or fungicidal against the pathogen. The MFC was demonstrated when no growth of the pathogen occurs on the subcultured medium [30,31].

\section{Identification of different ingredients in resin extract}

The identification of different ingredients from resin of $J$. procera involved both simple, preliminary phytochemical tests, and complex methods, thin layer and column chromatography. Silica gel (60-200 mesh) and silica gel (Kieselgel GF254 plates) (Merck) were used for column and thin layer chromatography respectively [31].

Preliminary phytochemical screen: Qualitative phytochemical tests of $J$. procera resin extract were carried out to identify the class of compounds by colour tests. A $10 \mathrm{~g}$ resin material was dissolved in methanol and dried using rotary evaporator. The resin extract was subjected to various standard phytochemical tests as follows.

1 Test for alkaloids: Hager's test was used to test the presence of alkaloids. To $1 \mathrm{ml}$ of extract, $3 \mathrm{ml}$ of Hageres reagent (saturated aqueous solution of picric acid) was added, and yellow colored precipitate indicated the presence of alkaloids [32].

2. Test for carbohydrates: The presence of carbohydrate and reduced sugar was tested using Molisch"s test [33]. Two (2) $\mathrm{ml}$ of the crude extract resin was transferred into $15 \mathrm{ml}$ test tube to which $1 \mathrm{ml}$ of $\alpha$-napthol solution was added and mixed. Then $1 \mathrm{ml}$ of concentrated sulphuric acid was added through the sides of the test tube. Purple or reddish violet color at the junction of the two liquids reveals the presence of carbohydrates.

3. Test for glycosides: Baljet"s test was used for glycosides; to $1 \mathrm{ml}$ of the test extract, $1 \mathrm{ml}$ of sodium picrate solution was added and the yellow to orange color reveals the presence of glycoside [34].

4. Test for steroids: Salkowski test was followed to detect the presence of steroids. One (1) mg crude extract resin was dissolved in chloroform $(3 \mathrm{ml})$ and equal volume of concentrated sulphuric acid was added. Formation of bluish red to cherry color in chloroform layer and green fluorescence in the acid layer represents the steroidal components [35].

5. Test for flavonoides: Alkaline reagent test was followed to test the presence of flavonoides. A few drops of sodium hydroxide solution was added into $2 \mathrm{ml}$ test extract; formation of an intense yellow color, which turned to colorless on addition of few drops of dilute hydrochloric acid indicated the presence of flavonoides [34].

6. Test for saponins: To $1 \mathrm{ml}$ of extract taken in a measuring jar, 9 $\mathrm{ml}$ of distilled water was added and shaken vigorously for 15 secound and extracts were allowed to stand for $10 \mathrm{~min}$. Formation of stable foam indicates the presence of saponins [35].

7. Test for fixed oils and fat: Spot and saponification tests were used for fixed oils and fats [32].

Spot test: a small quantity of resin extracts was pressed between the filter paper. Oil stains on paper indicates the presence of fixed oils.

Saponification test: To $1 \mathrm{ml}$ of the extract few drops of $0.5 \mathrm{~N}$ alcoholic potassium hydroxide were added along with a drop of phenolphthalein. The mixture was heated on a water bath for one and half hours. The formation of soap or partial neutralization of alkali indicated the presence of fixed oils and fats.

8. Test for tannins and phenolic compounds: Three phytochemical screening methods were used for tannins and phenolic compounds. To $2 \mathrm{ml}$ of each extract, a few drops of $10 \%$ lead acetate were added. 
The appearance of white precipitate indicates the presence of tannins [34]. To $1 \mathrm{ml}$ of the extract, $2 \mathrm{ml}$ ferric chloride solution was added; formation of a dark blue or greenish black color product shows the presence of tannins [32].

Alkaline reagent test: To $1 \mathrm{ml}$ of extract $1 \mathrm{ml}$ of sodium hydroxide was added gives yellow to red precipitate within short time showed the presence of tannins and phenolic compounds [32].

9. Test for terpenoids (Salkowski test): Five $\mathrm{ml}$ of extract, $2 \mathrm{ml}$ of chloroform was mixed and $3 \mathrm{ml}$ of concentrated $\mathrm{H}_{2} \mathrm{SO}_{4}$ was carefully added to form a layer. A reddish brown coloration of the inter face show positive results for the presence of terpenoids [5].

Column chromatography: A $36 \mathrm{~cm}$ long glass column was used and it was filled up to $25 \mathrm{~cm}$ with silica gel. Twenty (20) gram of resin was dissolved in methanol, which showed higher inhibitory activity during attempting inhibitory activity of crude extract of the resin at a concentration of $5 \mathrm{mg} / 100 \mathrm{ml}$ MEAP and dried using rotary evaporator. 60-200 mesh size silica gel suspended in methanol was used as a stationary phase. Then after the dried crude resin extract was fractionated into six fractions using different organic solvents were used as eluting solvent gradually with increasing order of polarity of solvents from non- polar to polar solvents (chloroform, ethyl acetate, ethanol and methanol) which is tabulated (Table 1) [22]. And all fractions were dried using Rota Vapor. Then $3 \mathrm{mg} / 100 \mathrm{ml}$ MEAP of each fraction was tested for its antifungal activity against $P$. demidoffii using the same procedure and methods that were used to test the antifungal activity of crude extract as mentioned in section 4.6.1.

Thin layer chromatography (TLC): All fractionated samples by column chromatography were dried using Rota Vapor. Resin extracts dissolved in methanol at a concentration of $2 \mathrm{mg} / \mathrm{ml}$ and were applied on TLC plates. The chromatograms were run using benzene and methanol (18:6) and benzene: ethanol: ammonia (18:2:1) as running solvent. At the end of the run, spots and bands on TLC plates were visualized under UV lights. Retention factor (Rf), which is a relative scale of the distance of the compound moved, calculated as Distance traveled by solute/distance traveled by solvent [31].

\section{Data analysis}

All the measurements were done in triplicate and the results were presented as mean $\pm \mathrm{SD}$. The statistical analysis was performed by oneway analysis of variance (ANOVA) followed by Post Hoc Multiple Comparison Tests using statistical software (SPSS) package version 17.0 for windows and $\mathrm{P}$ values $<0.05$ were considered as significant.

\section{Result and Discussion}

\section{Media formulation}

P. demidoffi was cultivated on different medium and the growth diameter was evaluated in four days interval in each media (Table 2). As indicated in Table 2, based on the growth diameter of $P$. demidoffii MEAP was a good medium for the cultivation of this fungus with growth diameter of $58.00 \pm 0.2 \mathrm{~mm}$ followed by LAM, with growth diameter of $57.00 \pm 0.17 \mathrm{~mm}$ after 24 days of incubation at $25^{\circ} \mathrm{C}$. CDA was the least with growth diameter $17.50 \pm 0.02$ after the same period of incubation. The growth of the fungus was thick in MEAP while its growth in LAM was too thin. Concerning the growth medium, there is no formal data on optimization of media for the cultivation of $P$. demidoffi.

\section{Antifungal assay}

Antifungal activity of resin (crude extract) on $P$. demidoffii: Organic solvent extracts of resin were tested against $P$. demidoffii using agar dilution method and the result is documented in Table 3 . Resin from $J$. procera significantly inhibited the growth of the fungus (P. demidoffii). The study in ref. [12] on the effects of oleoresins in

\begin{tabular}{|c|c|c|}
\hline Fraction & Percentage of solvent & Volume of solvent used \\
\hline Fraction 1 & $100 \% \mathrm{CHCl}_{3}$ & $50 \mathrm{ml}$ \\
\hline Fraction 2 & $25 \%{\mathrm{EtOAC:} 75 \% \mathrm{CHCl}_{3}}^{50 \mathrm{ml}}$ \\
\hline Fraction 3 & $50 \% \mathrm{EtOAC:} 50 \% \mathrm{CHCl}_{3}$ & $50 \mathrm{ml}$ \\
\hline Fraction 3 & $50 \% \mathrm{EtOAC:} 50 \% \mathrm{CHCl}_{3}$ & $50 \mathrm{ml}$ \\
\hline Fraction 4 & $100 \% \mathrm{EtOAC}$ & $50 \mathrm{ml}$ \\
\hline Fraction 5 & $50 \% \mathrm{EtOAC:} 50 \% \mathrm{MeOH}$ & $50 \mathrm{ml}$ \\
\hline Fraction 6 & $100 \% \mathrm{MeOH}$ & $50 \mathrm{ml}$ \\
\hline
\end{tabular}

Table 1: Organic solvents used as eluting solvent in column chromatography.

Note: $\mathrm{CHCl}_{3}$ : chloroform; EtOAC: Ethyl acetate; $\mathrm{MeOH}$ : Methanol.

\begin{tabular}{|c|c|c|c|c|c|c|}
\hline \multirow{2}{*}{$\begin{array}{l}\text { Culture } \\
\text { media }\end{array}$} & \multicolumn{6}{|c|}{ Measurement days } \\
\hline & $4^{\text {th }}$ day & $8^{\text {th }}$ day & $12^{\text {th }}$ day & $16^{\text {th }}$ day & $20^{\text {th }}$ day & $24^{\text {th }}$ day \\
\hline CMA & $5.50 \pm 0.05^{d}$ & $9.00 \pm 0.05^{e}$ & $12.00 \pm 0.05^{c}$ & $17.50 \pm 0.05^{d}$ & $19.00 \pm 0.1^{d}$ & $22.00 \pm 0.25^{d}$ \\
\hline CMDA & $8.50 \pm 0.05^{c}$ & $13.20 \pm 0.02^{d}$ & $15.00 \pm 0.05^{b}$ & $18.00 \pm 0.1^{d}$ & $18.80 \pm 0.05^{d}$ & $20.00 \pm 0.13^{e}$ \\
\hline CDA & $3.50 \pm 0.05^{e}$ & $5.60 \pm 0.03^{f}$ & $8.50 \pm 0.05^{d}$ & $12.50 \pm 0.05^{f}$ & $14.00 \pm 0.2^{\mathrm{e}}$ & $17.50 \pm 0.02^{f}$ \\
\hline JE & $2.40 \pm 0.02^{f}$ & $2.90 \pm 0.02^{g}$ & $5.60 \pm 0.02^{\mathrm{e}}$ & $15.00 \pm 0.1^{\mathrm{e}}$ & $19.00 \pm 0.17^{d}$ & $21.50 \pm 0.05^{\mathrm{e}}$ \\
\hline LAM & $11.00 \pm 0.1^{\mathrm{a}}$ & $17.00 \pm 0.05^{b}$ & $30.50 \pm 0.05^{a}$ & $39.00 \pm 0.1^{a}$ & $51.00 \pm 0.17^{a}$ & $57.00 \pm 0.17^{a}$ \\
\hline MEA & $11.00 \pm 0.1^{b}$ & $16.50 \pm 0.07^{b}$ & $30.00 \pm 0.5^{\mathrm{a}}$ & $36.50 \pm 0.05^{b}$ & $45.00 \pm 0.36^{b}$ & $52.00 \pm 0.2^{b}$ \\
\hline MEAJE & $3.20 \pm 0.32^{\mathrm{e}}$ & $5.30 \pm 0.03^{f}$ & $9.30 \pm 0.03^{c}$ & $16.00 \pm 0.1^{d}$ & $22.50 \pm 0.08^{c}$ & $25.30 \pm 0.17^{d}$ \\
\hline MEAP & $11.00 \pm 1.15^{a}$ & $18.00 \pm 0.1^{\mathrm{a}}$ & $31.00 \pm 0.1^{\mathrm{a}}$ & $39.00 \pm 0.26^{a}$ & $52.00 \pm 0.17^{a}$ & $58.00 \pm 0.2^{\mathrm{a}}$ \\
\hline OMA & $10.30 \pm 1.05^{b}$ & $13.70 \pm 0.02^{c}$ & $16.50 \pm 0.05^{b}$ & $20.50 \pm 0.05^{c}$ & $23.30 \pm 0.01^{c}$ & $26.30 \pm 0.17^{d}$ \\
\hline PDA & $10.00 \pm 1^{b}$ & $14.20 \pm 0.02^{c}$ & $17.50 \pm 0.04^{b}$ & $22.50 \pm 0.25^{c}$ & $24.30 \pm 0.02^{c}$ & $28.50 \pm 0.05^{\circ}$ \\
\hline
\end{tabular}

Table 2: The diameter growth of $P$. demidoffii (including the diameter of inoculum disc) in $\mathrm{mm}$ in each media and measurement date.

Note: Results are the mean values \pm standard deviations.

Means within the column under a parameter having a common letter do not differ significantly at $(p<0.05)$. 
Citation: Bitew D (2015) Assessment of the Inhibitory Activity of Resin from Juniperus procera against the Mycilium of Pyrofomes demidoffi. J Plant Pathol Microb 6: 291. doi:10.4172/2157-7471.1000291

an in vitro growth of fungi associated with pine decline showed that resin inhibited all tested fungi. The report in ref. [28] indicated that phytochemicals present in the Larrea tridentata resin have a powerful antifungal activity against Phytophthora capsici Leo. Which cause chili pepper (Capsicum annuum L.) wilt disease?

As shown in Table 3 the resin dissolved by methanol showed higher inhibitory activity against $P$. demidoffi with complete mycelial growth inhibition (100\%) at the concentration of $5 \mathrm{mg} / 100 \mathrm{ml}$ MEAP followed by ethyl acetate extract which completely inhibited the mycelia growth of the pathogen at $6 \mathrm{mg} / 100 \mathrm{ml}$ MEAP concentration after 20 days of incubation at $25^{\circ} \mathrm{C}$. Ethanol and chloroform extract were less effective with $66.19 \pm 0.02$ and $60.49 \pm 0.02$ percent of average mycelial inhibition of the pathogen respectively at $6 \mathrm{mg} / 100 \mathrm{ml}$ MEAP after the same period of incubation.

In terms of growth diameter and growth rate the growth diameter and growth rate of $P$. demidoffi were also highly reduced as compare to the control (Figure 1). The average growth diameter and growth rate of the P. demidoffii on control medium was $30.60 \pm 0.01 \mathrm{~mm}$ and 2.25 $\pm 0.03 \mathrm{~mm}$ respectively, but in resin containing medium was ranged from complete inhibition (no growth) to $26.30 \pm 0.04 \mathrm{~mm}$ respectively at highest and lowest concentration of resin extract, which depending on the solvent systems used.

Inhibitory activity of resin fractions again the mycelium of Pyrofomes demidoffii: In this study both crude and fractions poweders of the resin showed great inhibitory effect on the mycelial growth and growth rate of $P$. demidoffii (Table 4). Three (3) mg per 100 MEAP of each fraction was tested against $P$. demidoffii using agar dilution method. As indicated from below table fraction 3, 4 and 5 inhibited the mycelia a growth of the pathogen completely (100\% mycelial inhibition). Next to those potent fractions fraction 2 inhibited the

\begin{tabular}{|c|c|c|c|c|c|c|c|c|}
\hline \multirow{2}{*}{\multicolumn{2}{|c|}{ Solvent system }} & \multicolumn{7}{|c|}{ Concentration of resin $\mathrm{mg} / 100 \mathrm{ml}$ MEAP } \\
\hline & & \multirow{2}{*}{$\begin{array}{c}\mathbf{6} \\
12.30 \pm 0.01^{\mathrm{g}}\end{array}$} & \multirow{2}{*}{$\begin{array}{c}\mathbf{5} \\
13.80 \pm 0.01^{f}\end{array}$} & \multirow{2}{*}{$\begin{array}{c}4 \\
16.30 \pm 0.02^{\mathrm{e}}\end{array}$} & \multirow{2}{*}{$\frac{3}{18.60 \pm 0.03^{d}}$} & \multirow{2}{*}{$\begin{array}{c}2.5 \\
20.80 \pm 0.06^{c}\end{array}$} & \multirow{2}{*}{$\begin{array}{c}1.5 \\
26.30 \pm 0.04^{b}\end{array}$} & \multirow{2}{*}{$\begin{array}{c}\text { Control } \\
30.60 \pm 0.01^{a}\end{array}$} \\
\hline ह & $\mathrm{GD}(\mathrm{mm})$ & & & & & & & \\
\hline 은준 & $\mathrm{GR}(\mathrm{mm})$ & $0.9 \pm 0.1^{c}$ & $1 \pm 0.5^{\mathrm{bc}}$ & $1.2 \pm 0.1^{\mathrm{bc}}$ & $1.2 \pm 0.2^{\mathrm{bc}}$ & $1.3 \pm 0.1^{\mathrm{b}}$ & $1.9 \pm 0.1^{\mathrm{a}}$ & $2.25 \pm 0.03^{\mathrm{a}}$ \\
\hline & $\% \mathrm{INH}$ & $60.49 \pm 0.02^{a}$ & $50.17 \pm 0.03^{b}$ & $46.16 \pm 0.4 c$ & $37.32 \pm 0.03^{d}$ & $29.35 \pm 0.1^{\mathrm{e}}$ & $13.18 \pm 0.03^{f}$ & 0.00 \\
\hline \multirow{3}{*}{ 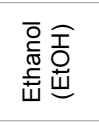 } & $\mathrm{GD}(\mathrm{mm})$ & $9.40 \pm 0.02^{\mathrm{e}}$ & $12.40 \pm 0.01^{\mathrm{de}}$ & $15.40 \pm 0.01^{\mathrm{cd}}$ & $17.20 \pm 0.02^{c}$ & $18.60 \pm 0.02^{\mathrm{c}}$ & $22.00 \pm 0.2^{\mathrm{b}}$ & $30.60 \pm 0.01^{\mathrm{a}}$ \\
\hline & $\mathrm{GR}(\mathrm{mm})$ & $0.6 \pm 0.1^{d}$ & $0.9 \pm 0.1^{\mathrm{cd}}$ & $1 \pm 0.6^{c}$ & $1.08 \pm 0.02^{c}$ & $1.14 \pm 0.03^{c}$ & $1.56 \pm 0.03^{b}$ & $2.25 \pm 0.03^{\mathrm{a}}$ \\
\hline & $\% \mathrm{INH}$ & $66.19 \pm 0.02^{\mathrm{a}}$ & $57.08 \pm 0.02^{\mathrm{b}}$ & $49.04 \pm 0.26^{c}$ & $40.28 \pm 0.48^{d}$ & $33.68 \pm 0.03^{e}$ & $23.82 \pm 0.02^{f}$ & 0.00 \\
\hline \multirow{2}{*}{ 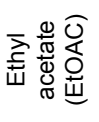 } & $\mathrm{GD}(\mathrm{mm})$ & - & $11.30 \pm 0.01^{f}$ & $13.10 \pm 0.02^{\mathrm{e}}$ & $16.90 \pm 0.01^{d}$ & $19.20 \pm 0.03^{c}$ & $22.90 \pm 0.01^{b}$ & $30.60 \pm 0.01^{a}$ \\
\hline & $\mathrm{GR}(\mathrm{mm})$ & - & $0.76 \pm 0.02^{\mathrm{e}}$ & $0.77 \pm 0.03^{e}$ & $1.14 \pm 0.02^{\mathrm{d}}$ & $1.3 \pm 0.02^{c}$ & $1.55 \pm 0.03^{b}$ & $2.25 \pm 0.03^{a}$ \\
\hline \multirow{3}{*}{ 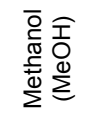 } & $\mathrm{GD}(\mathrm{mm})$ & - & - & $5.00 \pm 0.1^{e}$ & $9.00 \pm 0.1^{d}$ & $11.60 \pm 0.02^{c}$ & $13.30 \pm 0.03^{b}$ & $30.60 \pm 0.01^{a}$ \\
\hline & $\mathrm{GR}(\mathrm{mm})$ & - & - & $0.10 \pm 0.05^{d}$ & $0.57 \pm 0.01^{c}$ & $0.65 \pm 0.03^{b}$ & $0.68 \pm 0.02^{\mathrm{b}}$ & $2.25 \pm 0.03^{a}$ \\
\hline & $\%$ INH & $100^{\mathrm{a}}$ & $100^{a}$ & $79.85 \pm 0.02^{b}$ & $67.76 \pm 0.03^{c}$ & $58.36 \pm 0.03^{d}$ & $51.06 \pm 0.00^{e}$ & 0.00 \\
\hline
\end{tabular}

Table 3: In vitro inhibitory effect of resin from J. procera in the growth diameter, growth rate and percentage mycelial growth inhibition of $P$. demidoffii, dissolved by different solvent after 20 days of incubation at $25^{\circ} \mathrm{C}$.

Note: Results are the mean values \pm standard deviations. Means within the column under a parameter having a common letter do not differ significantly at ( $\mathrm{p}<0.05)$. $\mathrm{INH}$ percentage of mycelial inhibition. GD: Growth Diameter GR: Growth Rate -: No growth (100\% inhibition).

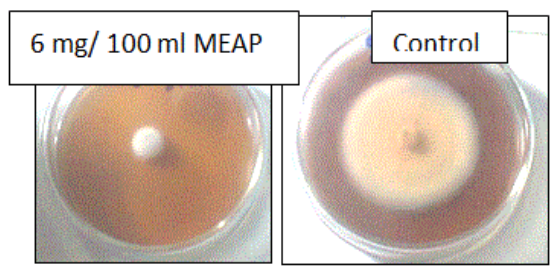

A

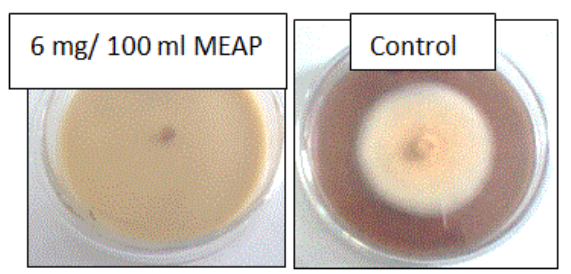

$\mathrm{C}$

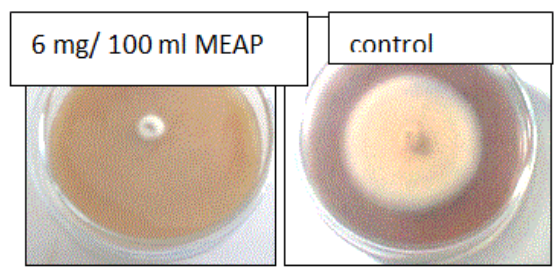

B

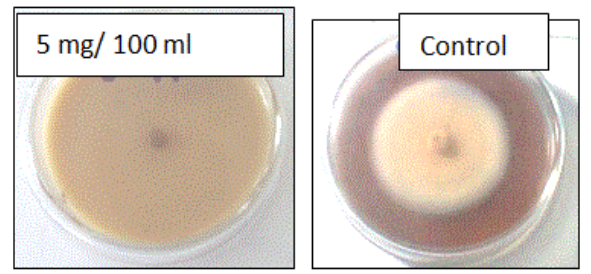

D

Figure 1: The inhibitory effect of resin extracted by different organic solvent against the mycelium of $P$. demidoffii Chloroform (A), Ethanol (B), Ethyl acetate(C) and Methanol (D) extract of resin. 


\begin{tabular}{|c|c|c|c|}
\hline Fractions & $\begin{array}{c}\text { Growth diameter } \\
\mathbf{( m m})\end{array}$ & Growth rate $\mathbf{( m m )}$ & \% inhibition \\
\hline Fraction 1 & $10.5 \pm 0.05^{\mathrm{c}}$ & $0.5 \pm 9^{\mathrm{c}}$ & $51.3 \pm 0.1^{\mathrm{c}}$ \\
\hline Fraction 2 & $5.5 \pm 0.01^{\mathrm{d}}$ & $0.49 \pm 0.1^{\mathrm{d}}$ & $75.85 \pm 0.05^{\mathrm{b}}$ \\
\hline Fraction 3 & - & - & $100^{\mathrm{a}}$ \\
\hline Fraction 4 & - & - & $100^{\mathrm{a}}$ \\
\hline Fraction 5 & - & - & $100^{\mathrm{a}}$ \\
\hline Fraction 6 & $13.7 \pm 0.03^{\mathrm{b}}$ & $0.92 \pm 0.2^{\mathrm{b}}$ & $35.5 \pm 0.1^{\mathrm{d}}$ \\
\hline Control & $22.7 \pm 0.05^{\mathrm{a}}$ & $1.92 \pm 0.03^{\mathrm{a}}$ & 0.00 \\
\hline
\end{tabular}

Table 4: Inhibitory effect of fractionated resin in growth diameter, growth rate and percentage mycelial growth inhibition of $P$. demidoffii after 18 days of incubation at $25^{\circ} \mathrm{C}$.

Note: Results are the mean values \pm standard deviations.

Means within the column under a parameter having a common letter do not differ significantly at $(p<0.05)$.

mycelial growth of the pathogen by $75.85 \pm 0.05 \%$. Fraction 6 was the most ineffective that inhibited the pathogen by $35 \%$.

In case of growth diameter and growth rate, the growth diameter and growth rate of the pathogen was highly reduced as compared to the control. The average growth diameter of the pathogen was $10.5 \pm 0.05$ $\mathrm{mm}, 5.5 \pm 0.01 \mathrm{~mm}$, no growth, no growth, no growth, $13.7 \pm 0.03 \mathrm{~mm}$ and $22.7 \pm 0.05 \mathrm{~mm}$ respectively on fraction $1,2,3,4,5,6$, and control medium (Table 4 and Figure 2). This gives an impressive clue for the increment of antifungal activity of bioactive elements within the resin when they are semi purified. The study in refs. [36,37] has confirmed that the strong antifungal property of semi purified extracts of several plants extracts.

\section{Minimum inhibitory concentration (MIC)}

The Minimum Inhibitory Concentration assay was also employed to evaluate the effectiveness of the resin to inhibit the growth of $P$. demidoffii. MIC value or resin was less as compared with commercial fungicides, this is may be due to its impurity mean the resin extract contains many compounds which may or may not involve in the inhibitory activity of the pathogen.

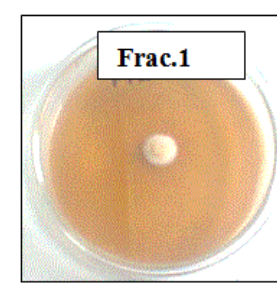

A

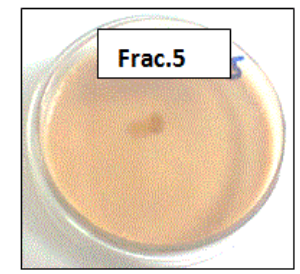

$\mathrm{E}$

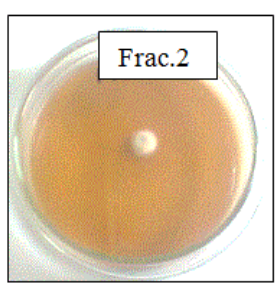

B

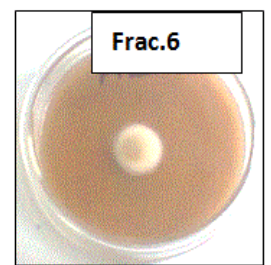

$\mathrm{F}$

MIC of resin was within the range of 5 to $6 \mathrm{mg} / 100 \mathrm{ml}$ MEAP. The resin was fungistatic against the pathogen and the result is recorded on Table 5. When the fungus inoculum plug, which do not show growth, removed from plate containing resin and placed on a plate containing pure medium, the fungus respond the fungistatic activity of resin, by growing more rapidly. The study in ref. [23] showed the fungisatic activity of oleoresin against pine colonizing fungi.

\section{Identification of active ingredient}

Preliminary phytochemical screen: Qualitative phytochemical tests of $J$. procera resin extract revealed the presence alkaloids, saponins, terpenoides, phenolic compounds, flavonoides and fixed oils, and the absence of carbohydrates steroids, fats, glycosides and tannins (Table 6 and Figure 3). According to ref. [38] conifer resin contains several phytochemical groups, composed primarily terpenoids and phenolic compounds. Based on the study in ref. [38] coniferous trees have diverse group of secondary metabolic compounds including isoflavonoids, pterocarpans, stilbenes and saponins as inducible defense systems. Pathogen induced accumulation of related constitutive antimicrobial compounds in coniferous has been reported [39], including stilbenes and diterpenic resin acids [40], lignans and flavonoids [41]. The study in ref. [42] reported that the wood and leaf oils of J. procera from Ethiopia and showed that the leaf oil contains pinene and limonene with a small quantity of borneol.

The study conducted in ref. [31] on the phytochemical analyses of resin from Spondias pinnata, showed the presence of flavonoids and fixed oils and the absence of saponins and tannins. In contrast to this, the report of ref. [43] indicated that conifers resins contain terpenoids, flavonids, phenolics, lignans and saponins. The study in refs. [30,43] showed that alkaloids, saponins, flavonoids stilbenes and phenolic compounds are among the biologically active secondary metabolites of plants that found in the resin of many conifers trees including leaves, bark and wood of trees. In agreement to the report of refs. [42,43] but in contrast to ref. [31] the phytochemical analysis of resin from $J$. procera revealed the presence of saponins and the absence of tannins.

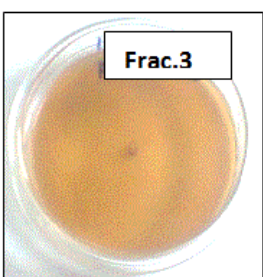

C

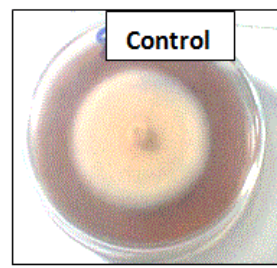

G

Figure 2: The antifungal activity of fractions against $P$. demidoffii A (frac.1), B (frac.2), C (frac.3), D (frac.4), E (frac.5), $\mathrm{F}$ (frac.6), G control) after 20 days of incubation at $25^{\circ} \mathrm{C}$. 


\begin{tabular}{|c|c|c|c|c|c|c|c|c|c|}
\hline \multirow{2}{*}{ Antifungal substance } & \multicolumn{3}{|c|}{$\begin{array}{c}\text { Concentration range } \\
\text { for fungicides (mg/100 } \\
\text { ml of MEAP) }\end{array}$} & \multicolumn{4}{c|}{$\begin{array}{c}\text { Concentration range for } \\
\text { resin in mg/100 ml of MEAP }\end{array}$} \\
\cline { 2 - 11 } & $\mathbf{0 . 1}$ & $\mathbf{0 . 2 5}$ & $\mathbf{0 . 5}$ & $\mathbf{1}$ & $\mathbf{4}$ & $\mathbf{5}$ & $\mathbf{6}$ & $\mathbf{7}$ & $\mathbf{8}$ \\
\hline $\begin{array}{c}\text { Resin dissolved by } \\
\text { MeOH }\end{array}$ & & & & & + & $*$ & - & - & - \\
\hline $\begin{array}{c}\text { Resin dissolved by } \\
\text { EtOAC) }\end{array}$ & & & & & + & + & $*$ & - & - \\
\hline Redomil Gold MZ & + & $*$ & - & - & & & & & \\
\hline Sancozeb 80 WP & + & + & $*$ & - & & & & & \\
\hline Cruzate R WP) & + & + & + & $*$ & & & & & \\
\hline
\end{tabular}

Note: - (*) MIC. (+) Growth of fungus observed. (-) no growth of fungus.

Table 5: Minimum Inhibitory Concentration (MIC) for crude extracts resin and fungicides against $P$. demidoffii.

\begin{tabular}{|c|c|}
\hline Phytochemicals & Presence (+)/absence (-) \\
\hline Alkaloids & + \\
\hline Saponins & + \\
\hline Terpenoides & + \\
\hline Phenolic compounds & + \\
\hline Flavonoides & + \\
\hline fixed oils & - \\
\hline Carbohydrates & - \\
\hline Steroids & - \\
\hline Fats & - \\
\hline Glycosides & - \\
\hline Tannins & \\
\hline
\end{tabular}

Table 6: Phytochemical constituents of resin from Juniperus procera.
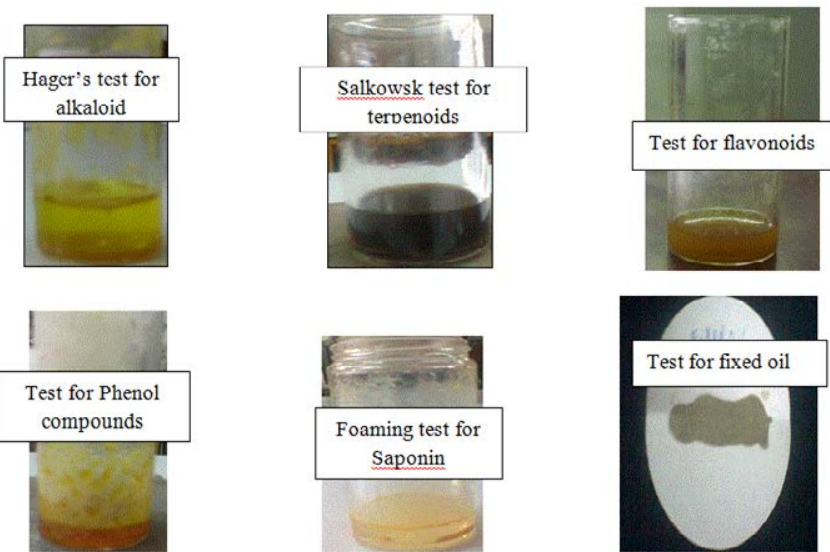

Figure 3: Preliminary phyotochemical test of resin for a class of compounds.

The difference on the composition of resin may be due to the difference in the plant species, fungal species and environment in which the tree grows. Although plants have the capacity to produce and store different amounts of secondary metabolites the properties and composition of these compounds may vary according to the producer organism's environment [44]. The observed antifungal activity is might be attributed to the presence of these bioactive compounds in the resin crude extract and the effect may be due to a single compound or may be a combined effect of different compounds present in the resin extract. The presence of alkaloids, saponins, terpenoids, phenolic compounds and flavonoids from resin extract is known to confer antifungal activity against plant pathogenic fungi [45].

Thin layer chromatography (TLC): Thin layer chromatography (TLC) was carried out with a moderately non-polar solvent system using benzene: methanol (18:6) and benzene: ethanol: ammonia (18:2:1). The Retention factor (RF) value of each fraction were calculated and tabulated below (Table 7). Bands and different spots were observed under UV lights. As shown in Table 7 each fraction gave different Rf values in two different solvent systems. This variation in $\mathrm{Rf}$ values of the fractions provides a very important clue in understanding of their polarity. The Rf values of phytochemicals in faction 1 were $0.68,0.78$ and $0.60,0.72$ respectively in two solvent system Benzene: Methanol (18:6) and Benzene: Ethanol: Ammonia (18:2:1), which are moderately non-polar. Whereas the $\mathrm{Rf}$ values phytochemicals in fraction 6 were $0.18,0.25$ and 0.42 .0 .38 respectively in two solvent system, Benzene: Methanol (18:6) and Benzene: Ethanol: Ammonia (18:2:1). The Rf values of phytochemicals in fraction 1 were greater than the $\mathrm{Rf}$ values of phytochemicals in fraction 6 in similar solvent system, which showed the non-polarity of phytochemicals within fraction 1 as compared to fraction 6. Compound showing high $\mathrm{Rf}$ value in less polar solvent system have low polarity and with less Rf value have high polarity [46].

\section{Conclusion and Recommendations}

\section{Conclusion}

The evaluation of growth diameter of $P$. demidoffii on diffserent media demonstrated, as MEAP is a good medium for the cultivation of P. demidoffii.

The results of this study showed that, resin from J. procera has significant inhibitory effect against $P$. demidoffii. Both fractions and crude extract of resin have a greatest inhibitory effect on $P$. demidoffii. It can be used as potential candidates for the formulation of bio fungicides, which may be useful in the treatment of Juniper procera heart rot, chocolate spot disease, tomato and coffee wilt disease.

TLC profiling reveals the presence of various phytochemicals within the resin of $J$. procera.

The results of phytochemical tests, of resin from J. procera showed the presence of alkaloids, saponins, terpenoids, phenolic compounds, flavonoides and fixed oils.

\section{Recommendations}

Further research is needed to purify bioactive elements, especially fraction 3,4 , and 5 in the resin

Only a few genera of fungal groups were used in the study. Antifungal tests are recommended to be done on more species which are important to plant health.

The results described above did not tell the possible inhibitory mechanisms of the resin, mechanisms of $P$. demidoffii for infestation of $J$. procera (enzymatic or phytotoxic) and method of extraction of

\begin{tabular}{|c|c|c|c|}
\hline \multirow[b]{2}{*}{ Fraction } & \multirow[b]{2}{*}{ Extraction solvent } & \multicolumn{2}{|c|}{ Developing solvents } \\
\hline & & \begin{tabular}{c|} 
Benzene: \\
Methanol (18:6)
\end{tabular} & $\begin{array}{l}\text { Benzene: Ethanol: } \\
\text { Ammonia (18:2:1) }\end{array}$ \\
\hline Fraction 1 & $100 \% \mathrm{CHCl}_{3}$ & $0.68,0.78$ & $0.60,0.72$ \\
\hline Fraction 2 & $25 \%$ EtOAC: $75 \% \mathrm{CHCl}_{3}$ & $0.50,0.56$ & 0.64 \\
\hline Fraction 3 & $50 \%$ EtOAC: $50 \% \mathrm{CHCl}_{3}$ & $0.50,0.55,0.62$ & $0.48,0.60$ \\
\hline Fraction 4 & $100 \%$ EtOAC & $0.46,0.62,0.67$ & $0.45,0.56$ \\
\hline Fraction 5 & $50 \%$ EtOAC: $50 \% \mathrm{MeOH}$ & $0.41,0.52$ & 0.50 \\
\hline Fraction 6 & $100 \% \mathrm{MeOH}$ & $0.18,0.25$ & 0.42 .0 .38 \\
\hline
\end{tabular}

Note: $\mathrm{CHCl}_{3}$ : Chloroform EtOAC: Ethyl acetate $\mathrm{MeOH}$ : Methanol.

Table 7: Retention factor (RF) of different solvent fractions of resin extract through column chromatography. 
Citation: Bitew D (2015) Assessment of the Inhibitory Activity of Resin from Juniperus procera against the Mycilium of Pyrofomes demidoffi. J Plant Pathol Microb 6: 291. doi:10.4172/2157-7471.1000291

enzymes or toxins that $P$. demidoffii use to attack $J$. procera tree, so it require further investigation.

\section{References}

1. Pohjonen V, Pukkala T (1992) Juniperus procera Hocht. ex Endl. in Ethiopian forestry. For Ecol and Mgt 49: 75-85.

2. Von Breitenbach $F(1963)$ The indigenous Trees of Ethiopia. 2nd ed. Ethiopian Forestry Association, Addis Ababa, Ethiopia, pp. 305.

3. Gessesse D (2007) Forest Decline in South Central Ethiopia: Extent, history and process. Department of Physical Geography and Quaternary Geology Stockholm University, Stockholm, Sweden.

4. Nyssen J, Poessen J, Moeyersons J, Deckers J, Haile M, et al. (2004) Human impact on the environment in the Ethiopian and Eritrean highlands - a state of the art. Earth-Science Reviews 64: 273-320.

5. Chaffey DR (1982) South-west Ethiopia forest inventory project. A reconnaissance inventory of forests in south-west Ethiopia. Addis Ababa, Forestry and Wildlife Conservation and Development Authority.

6. Contreras-Hermosilla A (2000) The underlying causes of forest decline. Occasional Paper No. 30. Centre for International Forestry Research (CIFOR). Bogor

7. Eckhardet LG, Weber AM, Menard RD, Jones JP, Hess NJ (2007) Insectfungal complex associated with loblolly pine decline in central Alabama. For Sci 53: 84-92

8. EFAP (Ethiopian Forest Action Program) (1994) Ethiopian Forest Action Program Vol.2 Ministry of Natural Resources Development and Environmental Protection, Addis Ababa, Ethiopia.

9. Achalu Negussie (1995) Monographic review on Juniperus excelsa. Alemaya University of Agriculture, Faculty of Forestry, pp: 4

10. Ryvarden L, Johansen I (1980) A Preliminary Polypore Flora of East Africa. Oslo: Fungi flora

11. Tigabu M, Fjellström J, Odén P, Teketay D (2006) Germination of Juniperus procera seeds in response to stratification and smoke treatments, anddetection of insect-damaged seeds with VIS + NIR spectroscopy. New Forests 33: 155169

12. Eckhardt LG, Menared RD, Gray DE (2008) Effects of oleoresins and monoterpenes on in vitro growth of fungi associated with pine decline in the Southern United States. For Path 39: 157-167.

13. Scharpf RF, Goheen D (1993) Heart rots, In: Diseases of Pacific Coast Conifers Forest Service Agriculture Handbook, (Scharpf, R.F. eds). United States Department of Agriculture, Washington, DC. pp: 150-180

14. Abou-Zeid AM, Altalhi AD, Abd El-Fattah RI (2007) Fungal control of pathogenic fungi isolated from wild plants in Taif Governorate, Saudia Arabia. Roum Arch Microbiol Immunol 66: 90-96.

15. Gilbertson RL, Ryvarden L (1987) North American Polypores, Vols. I and II. Fungiora. Oslo, pp: 885

16. Pataky NR (1999) Wood rots and decays report on plant disease. RPD No. 642. University of Illinois at Urbana-Champaign

17. Cos P, Vlietinck AJ, Berghe DV, Maes L (2006) Anti-infective potential of natural products: how to develop a stronger in vitro 'proof-of-concept'. J Ethnopharmacol 106: 290-302.

18. Wagener WW, Davidson RW (1954) Heart rots in living trees. Bot Rev 20: 61 134.

19. Zwenger S, Basu C (2008) Plant terpenoids: applications and future potentials Biotechnology and Molecular Biology Reviews 3: 001-007.

20. Berryman AA (1972) Resistance of conifers to invasion by bark beetle-fungus associations. Bio Science 22: 598-602.

21. Martin DM, Tholl D, Gershenzon J, Bohlmann J (2002) Methyl jasmonate induces traumatic resin ducts, terpenoid resin biosynthesis, and terpenoid accumulation in developing xylem of Norway spruce stems. Plant Physiol 129 1003-1018.

22. Miller B, Madilao LL, Ralph S, Bohlmann J (2005) Insect-induced conife defense. White pine weevil and methyl jasmonate induce traumatic resinosis dnovo formed volatile emissions, and accumulation of terpenoid synthase and putative octadecanoid pathway transcripts in Sitka spruce. Plant Physiol 137: 369-382.
23. Chang SS, Ostic- Matijaesievic B, Hsieh OA, Huang CL (1977) Natural antioxidant from rosemany and sage. J Food Sci 42: 1102 - 1106

24. Hajlaoui H, Trabelsi N, Noumi E, Snoussi M, Fallah H, et al. (2009) Biological activities of the essential oils and methanol extract of tow cultivated mint species (Mentha longifolia and Mentha pulegium) used in the Tunisian folkloric medicine. World J Microbiol Biotechnol 25: 2227-2238.

25. Lee CH, Lee HS (2005) Antifungal property of dihydroxyanthraquinones against phytopathogenic fungi. J Microbiol Biotechnol 15: 442-446.

26. Food and Agricultural Organization of United State (FAO) (2011) AGP Integrated Pest Management fact sheet.

27. Bitew A (2010) Antibacterial and antifungal of culture filtrate extract of Pyrofomes demidoffii. Independent research, Addis Ababa University, Addis Ababa, Ethiopia.

28. Mojica-Marin V, Luna-Olvera HA, Sandoval-Coronado CF, MoralesRamose LH, Gonzalez-Aguilar NA, et al. (2011) In vitro antifungal activity of "Gobernadora" (Larrea tridentata (D.C.) Coville) against Phytophthora capsici Leo. Afr J of Agric Res 6: 1058-1066.

29. Zadoks JC, Schein RD (1979) Epidemiology and plant disease management Oxford University Press. USA, pp: 427.

30. Celimene CC, Smith DR, Young RA, Stanosz GR (2001) In vitro inhibition of Sphaeropsis sapinea by natural stilbenes. Phytochemistry 56: 161-165.

31. Gupta VK, Roy A, Nigam V, Mukherjee K (2010) Antimicrobial activity of Spondias pinnata resin. Journal of Medicinal Plants Research 4: 1656-1661.

32. De S, Dey YN, Ghosh AK (2010) Phytochemical investigation and chromatographic evaluation of the different extracts of tuber of amorphaphallus paeoniifolius (araceae). Int $\mathrm{J}$ on Pharm and Biomed Res. 1: 150-157.

33. Njoku OV, Obi C (2009) Phytochemical constituents of some selected medicinal plants. African Journal of Pure and Applied Chemistry 3: 228-233.

34. Neelima N, Devidas NG, Sudhakar M, Kiran J (2011) A preliminary phytochemical investigation on the leavse of Solanum xanthocarpum. Int $\mathrm{J}$ of Res in Ayurveda and Pharm. 2: 845-850.

35. Harborne JB (1996) Phytochemical Methods. Chapman and Hall Ltd., London, Pp: 52-105.

36. Edeoga HO, Okwu DE, Mbaebie BO (2005) Phytochemical constituents of some Nigerian medicinal plants. Afr J of Biotechnol 4: 685-688.

37. Pretorius JC, Zietssman PC, Eksteen D (2002) Fungitoxic properties of selected South African plant species against plant pathogens of economic importance in agriculture. Ann. Appl Biol 141: 117-124

38. Kopper BJ, IIIman BL, Kersten PJ, Klepzig KD, Raffa KF (2005) Effects of diterpene acids on components of a conifer bark beetle-fungal interaction: tolerance by Ips pini and sensitivity by its associate Ophiostoma ips. Environ Entomol 34: 486-493.

39. Pearce RB (1996) Antimicrobial defences in the wood of living trees. New Phytol 132: 203- 233.

40. Bonello P, Heller W, Sandermann JH (1993) Ozone effects on root disease susceptibility and defence responses in mycorrhizal and nonmycorrhizal seedlings of Scots pine (Pinus sylvestris L.). New Phytol 124: 653- 663.

41. Adams RP (1990) Junipers procera East Africa: volatile leaf oil composition and putative relationship to J. excelsa. Biochem Syst and Ecol 18: 207- 210

42. Raffa KF, Berryman AA (1982) Accumulation of monoterpenes and associated volatiles following fungal inoculation of grand fir with a fungus transmitted by the fir engraver Scolytus ventralis (Coleoptera: Scolytidae). Can Entomo 114: 797-810.

43. Lieutier $F$ (2002) Mechanism of resistance in conifers and bark beetle attack strategies, In: Mechanisms and Development of Resistance in Trees to Insects, (Wagner, M. R.; Clancy, K. M.; Lieutier, F.; Paine, T. D. Ed). Dordrecht: Kluwer Academic Publishers pp: 31-78.

44. Firn RD, Jones CG (2003) Natural products--a simple model to explain chemical diversity. Nat Prod Rep 20: 382-391.

45. Farnsworth AC (1982) The role of ethnopharmacology drug development from plants. England Ciba: John Wiley and Sons. Pp: 2-10.

46. Siddiqui AA, Ali M (1997) Practical pharmaceutical disease 1st edn. CBS Publisher and distributions, New Delhi. Pp: 126-131. 